\title{
THE LEGISLATIVE BACKGROUND OF THE APPLICATION OF FERMENTATION RESIDUES TO AGRICULTURAL LANDS IN HUNGARY
}

\author{
${ }^{1}$ Attila Barczi, ${ }^{1}$ Dániel Szalai, ${ }^{2}$ Valeria Nagy \\ ${ }^{1}$ Szent István University, Faculty of Agricultural and Environmental Sciences, \\ Environmental Protection and Landscape Ecology Department, Páter K. str. 1, 2100 Gödöllö, Hungary \\ e-mail: barczi.attila@mkk.szie.hu; szalai.daniel@mkk.szie.hu \\ ${ }^{2}$ University of Szeged, Faculty of Engineering, Moszkvai Bld. 9., 6725 Szeged, Hungary \\ e-mail: valinagy78@mk.u-szeged.hu
}

\begin{abstract}
The broad presence of biogas plants - facilities using organic wastes and by-products to generate energy - now seems to warrant urgent attention to the land application of by-products (fermentation residues) from biogas plants. In Hungary, this activity can be carried out under statutory conditions, subject to official licensing. The protection provided by law is necessary because an adaptable and sustainable agriculture based on effects and interactions also requires such attention, since the most important natural resource of agriculture is soil, which, by nature, is a conditionally renewable natural resource [1] [2]. Protection of soil means primarily protection of quality: sustainable and adaptable agriculture contributes to retain the ecological functions of soil and its role in the ecosystem [3]. This publication analyses the possibilities and challenges of natural resource management by studying the agricultural use of fermentation residues from biogas plants. In order to be used in agriculture, fermentation residue should be classified according to its character and nutritional value, namely as harmless waste from non-agricultural sources. This substance may have the properties of slurry, and in certain cases it may be classified as a substance with characteristics of waste water/sewage sludge or sewage sludge compost.

Main elements of the preparation of the soil protection plan: detailed laboratory tests of the fermentation residue according to standards and regulations; classification of the fermentation residue on the basis of the measured parameters and the field tests corresponding to the character of fermentation residue according to the relevant legislation. Soil protection plan is prepared by expert based on on-site investigation and laboratory reports. This is the basis of the licensing process.

Land application of fermentation residues therefore requires expert analysis to ensure that the ecological functions of soil are not damaged. This, however, requires that the regulations governing the framework for the conditions of such application are carefully studied and interpreted.
\end{abstract}

Keywords: fermentation residue, arable land, soil test

\section{INTRODUCTION}

The problem of meeting energy demands in a safe, effective and economical way can currently be solved by combining traditional and renewable energy sources in a harmonized manner. At the dawn of a new era in energy economics, the reason for producing and using renewable energy sources, including biogas, is justified not only by energetically considering, but also by those of waste management, environmental protection and economy, which is also confirmed by life cycle assessments [4]. Biogas plants are typically established and operated in order to manage various wastes and by-products of vegetable and animal origin. Some of these substances are not directly re-workable into the soil, but they are biodegradable: as a result of the fermentation of various organic materials in the absence of oxygen, biogas is produced with the aid of bacteria. The input of this biogas producing process is biomass and energy, while the output is biogas and fermentation residue [5] [6]. Biogas plants established for the management of agricultural and food wastes and by-products are notable inasmuch some of these substances could otherwise easily become harmful to the environment (and to the soil) if not treated properly.

Another aspect of the perception of biogas production concerns the amount of organic matter required to maintain soil fertility. Natural ecosystems are characterized by a dynamic balance of accumulating and degrading organic matter. In case of ecosystems affected by human influence, such dynamic balance can be ensured without causing harm to nature by creating and maintaining the conditions which are necessary to retain, supply and appropriately break down the organic matter in soil [7] [8] [9]. 
Fermentation residues - under certain conditions and in accordance with relevant requirements - can be reworked into the crop cycle in order to replenish nutrients in the soil. It must be emphasized, however, that the basis for the application of fermentation residues from biogas plants to soil / agricultural lands lies in the making of scientific studies that take the relevant regulatory background into account, as well. The application of fermentation residue to soil / agricultural lands depend on its nutritional qualities. It is precisely the varying nutrition content and the technologies used in the process that necessitate the classification of fermentation residue. Application to agricultural lands in Hungary can occur in a controlled manner, i.e. based on professional principles enshrined in legislation, according to a professional plan, authorized by soil protection authorities.

The protection of soil as a conditionally renewable energy source vs. land application of by-products both requires basic information about soil. The importance of these is strikingly highlighted by the fact that the situation analysis by the Thematic Strategy for Soil Protection and the Framework for the Protection of Soil that emerged in 2006 both focus on the importance and condition of soils: "Soil degradation is a serious problem in Europe. It is driven or exacerbated by human activity such as inadequate agricultural and forestry practices, industrial activities, tourism, urban and industrial sprawl and construction works. These activities have a negative impact, preventing the soil from performing its broad range of functions and services to humans and ecosystems." In accordance with these guiding principles in Hungary, under Act CXXIX of 2007 on the protection of arable land [10], it is our common task to sustain the fertility of agricultural lands. In the light of this objective, this publication analyzes the joint areas of legislation and practice concerning soil, as well as parts of the legislative environment which are meant to secure the ecological functions of soil and its roles in the ecosystem.

\section{THE VULNERABILITY OF SOILS AND THE IMPORTANCE OF SOIL PROTECTION}

Soil is a complex, natural formation of the surface, natural in origin and composed of mineral and organic materials, serving as a habitat and terroir for plants and other organisms [11]. Soil is an integrator, reactor and transformer of other natural resources: it is the place of biomass production, the natural storage location of temperature, nutrients and water [12]. With environmental concerns coming to the forefront it has become clear that the protection of the condition of soil (as an object of environmental protection) is essential, since soil is a natural filter and a high capacity buffering medium, while its role in protecting nature is also important. The consideration of all these functions require a much more differentiated, varied and subtle attitude towards the use of soil [2] [13].

The protection of soils is a priority. It is, however, necessary to consider first that the erosion of fertile soil has accelerated because of "industrial" farming methods, involving now significant areas (40-50\% of Hungary), even though about $25 \%$ of the total national wealth of Hungary lies in the value of arable land [14]. Therefore, from the viewpoint of the continuous operation of biogas plants, the careful planning of soil nutrition management and the prevention of the contamination of soil are of paramount importance. The most important problem that rises during planning is the inhomogeneity of fermentation residue. Closely connected to soil, the quality of water is also notable, especially important in case of underground water resources [14]. The contamination with by-products from biogas plants in nitrate vulnerable zones with LPIS (Land Parcel Identification System) block identification numbers urges utmost caution in these matters. Note here that from 1 September 2013, more than $69 \%$ of the area of Hungary has been designated nitrate vulnerable.

Based on the above, it is becoming clear that any intervention in the soil should be made relying on expertise from experience, insight, as well as professional principles and guidelines included in legislation. Different types of soil react to fluid load differently, are classified differently according to their vegetable nutrition in their habitat, and they have different filtering capacities. Therefore, the land application of fermentation residues from biogas plants should be based not only on the general description of affected 
soils and soil types, but also on the precise comprehension of the buffering capacity of soils, the limits of the application of by-products, as well as the physical/chemical characteristics of by-products.

\section{REQUIREMENTS FOR A SOIL-CONSERVING AGRICULTURE}

From the viewpoint of an agriculture that aims to use land in harmony with the environment and sustain the ecological functions of soil, familiarity with the guidelines, strategies and regulations, including but not limited to the ones presented and organized below, as well as their proper and responsible practical application, may secure the protection of soil.

The preamble to the thematic strategy for soil protection [15] points out the complex role of soil: it is soil that provides us with food, biomass and raw materials. From these functions, the Alpine Convention highlights the conservation of the ecological functions of soil, therefore committing itself to prevent degradation of soil. Also, under the proposed directive $\operatorname{COM}(2006) 232$ [16], member states may adjust provisions of the thematic strategy for soil protection to the actual local circumstances.

The protection of soil and the maintenance of its fertility is important not only for the user/farmer of the land, but also for the whole society in the long run, since in many cases it is because of improper land use and an agriculture disregarding soil protection that soil degradation develops, entailing reduced soil fertility and the pollution of waters and drinking water supplies.

Under Annex II to Regulation 1306/2013/EU on the financing, management and monitoring of the common agricultural policy [17], each member state should lay down the provisions concerning the Standards for Good Agricultural and Environmental Condition (GAEC), complying with the Statutory Management Requirements (SMR). Provisions concerning the standards for Good Agricultural and Environmental Condition (GAEC) and those regulations of the Statutory Management Requirements (SMR) which are concerned with the protection of waters against pollution caused by nitrates from agricultural sources (SMR1), as well as some of their main characteristics are given in Tab. 1. The aims of GAEC include the maintenance of agricultural lands in good agricultural and ecological condition, while SMR1 aims at the reduction of water pollution caused by nitrates from agricultural sources and the prevention of such pollution in nitrate vulnerable areas. In this area it is especially important to observe the rules and regulations of Good Agricultural Practices (GAP).

Table 1. The cross-compliance system (excerpt) from the Cross Compliance Handbook for Farmers

\begin{tabular}{ccccccc}
\hline & $\begin{array}{c}\text { land } \\
\text { area }\end{array}$ & $\begin{array}{c}\text { farming in nitrate } \\
\text { vulnerable area }\end{array}$ & $\begin{array}{c}\text { sewage } \\
\text { sludge }\end{array}$ & $\begin{array}{c}\text { Natura } \\
\mathbf{2 0 0 0} \text { area }\end{array}$ & $\begin{array}{c}\text { animal } \\
\text { husbandry }\end{array}$ & agronomy \\
\hline GAEC & + & + & + & + & + & + \\
SMR1. & & + & & & + \\
\hline
\end{tabular}

Professional considerations and guidelines based on scientific foundations are usually contained in legislation.

Within the applicable laws, Act LIII of 1995 on the General Rules for the Protection of the Environment [18], land is to be considered an environmental element. Protection of the land involves protection of the soil, including also the protection of the soil's fertility, structure, water and air balance, as well as its organisms. This act also stipulates that on the surface of or in the soil only such activities may be carried out and only such substances may be deposited which do not contaminate or damage the quantity, quality and processes of soil and the environmental elements. Note here that in case of agriculture, based on local and individual circumstances and practical experience, it is possible to give support to a given activity. This gives a key role to professional experts.

Act LIII of 1996 on the Protection of Nature [19] is related to this topic by reason of farming on Natura 2000 areas. It contains the concept of a nature-friendly farming method: a farming method, which, as part of sustainable use, affects natural values, areas and biodiversity to such an extent that their natural or near natural state remains. 
Act CXXIX of 2007 on the protection of arable land [10] specifies what activities are subject to official licensing by soil protection authorities, such as the conditions of the application of slurry to arable land; of the agricultural use of waste water, sewage sludge and sewage sludge compost; of the application of hazardous and harmless wastes from non-agricultural sources to arable land; of the application of harmless agricultural wastes to arable land, possibly including fermentation residues.

\section{THE APPLICATION OF FERMENTATION RESIDUES FROM BIOGAS PLANTS TO AGRICULTURAL LANDS}

Agricultural activity involves an increased use of soil, which must be kept under constant control to ensure the long-term well-being of humanity. In this respect it is important to fix the conditions and circumstances for the applicability of organic matter to arable land or to the soil.

The application of fermentation residues from biogas plants is one of the most common problems for both the farmer and the expert. As described above, fermentation residue is formed by the anaerobic degradation of starting materials of various character, and during the fermentation it comes into contact with other materials used in the technology. Therefore, application to arable land may largely depend on the properties of the fermentation residue. It is normally classified as harmless waste from sources other than agriculture. Application to arable land is an activity which requires authorization, therefore the professional interpretation of the relevant provisions of FVM Decree No. 90/2008. (VII. 18.) is necessary [20].

The permit is issued by the soil protection authority, in the possession of a plan designed by a pedologyic expert. Based on a review of several recent soil protection plans, the problems that may arise during the licensing process can be summarized as follows:

- The client who wishes to dispense the fermentation residue is unaware of the requirements for the land application and the classification of the substance.

- The pedologic expert and the accredited laboratory do not perform the tests (or have them performed) as prescribed by the Hungarian Standard, or the measurement is not based on the standard assigned to that parameter.

- In most biogas fermenters, there are substances (e.g. heavy metals) that justify the compulsory tests for sewage / sewage sludge. Therefore it is not enough to simply analyses of nutrient content.

Eliminating all of this requires accuracy, discipline and strict compliance with the statutory regulations by the client, the expert and the laboratory alike. The following flow diagram (Fig. 1) shows the steps required for successful authorization procedures.

The detailed rules of land application in accordance with the concerns of soil protection in Hungary are contained in the legislation referred to in the flowchart. An important tool for the practical implementation of soil protection is the soil protection plan, which is a kind of link between the farmer and the authority.

Detailed rules for the preparation of the soil protection plan are set out in FVM Decree No. 90/2008. (VII. 18.) [20]. The plan types associated with the application of fermentation residues from biogas plant to agricultural land as prepared by the soil protection expert can fall into any of the following:

- $\quad$ soil protection plan for the use of slurry in agricultural areas

- $\quad$ soil protection plan for the use of waste water and sludge slurry in agricultural areas

- $\quad$ soil protection plan for the use of harmless wastes from non-agricultural sources in arable land 
selection of an expert who is registered in an expert list and qualified to perform the activity

name of the substances entering biogas plants,

a precise description of fermentation technology

\author{
$+$
}

the qualification of the fermentation residue based on input materials and fermentation technology expert decision

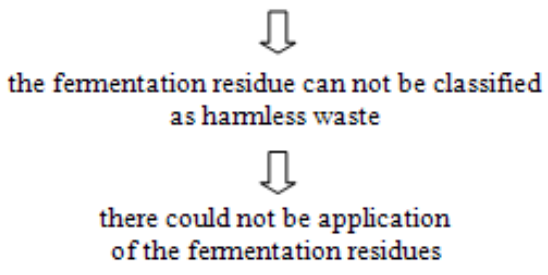

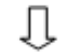

if the starting materials do not contain hazardous waste, the fermentation residue may be classified as hamless waste from non-agricultural sources under point 2.11 of FVM Regulation 90/2008. (VII. 18.)

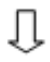

creation of a soil protection plan under FVM Regulation 90/2008. (VII. 18.)

the expert performs the morphological examination of the<smiles>[CH]1CCCC1</smiles>
fermentation residue

accredited sampling from the fermentation residue<smiles>C1=CC=C1</smiles>

in order to determine the nature of the fermentation residues, it is appropriate to carry out the inspections pursuant to Govt. Regulation 50/2001. (IV.3.) in an accredited laboratory according to the relevant Hungarian Standard, then an expert decision on the<smiles>C1=CC=C1</smiles>

if the fermentation residue does not contain toxic, harmful substances, the land application is carried out on the basis of the slurry specifications - preparation of a soil protection plan according to point 2.7 of FVM Regulation 90/2008. (VII. 18.) basis of the results<smiles>C1=CC2CCC=C12</smiles>

if there are toxic substances in the fementation residue, the land application is based on the requirements for waste water/ sewage sludge - preparation of a soil protection plan according to point 2.8 of FVM Regulation 90/2008. (VII. 18.)

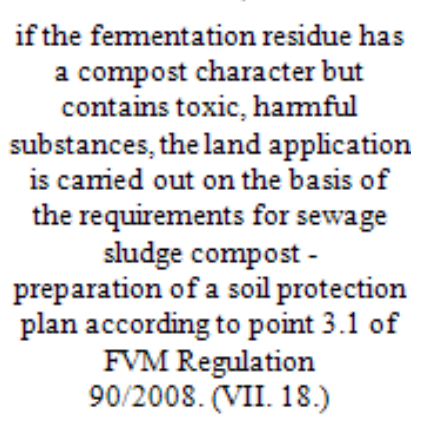

Figure 1. Activities to be performed before the land application of by-products from biogas plants

Pedologic investigations grounding the soil protection plan and the examination of the substances to be applied shall be carried out using the standards set out in this regulation or according to an equivalent accredited method. Examinations may only be carried out by accredited laboratories on the basis of the relevant Hungarian Standard. For soil sampling, the regulation itself and the manuals of the farmers provide guidance with illustrations. It should be noted here that the soil data contained in the soil protection plan are recorded by the soil protection authority in a soil database.

Point 2.11 of Annex 2 of FVM Decree No. 90/2008. (VII. 18.) is clear in terms of the criteria to be met if the fermentation residue is to be applied to arable land [20]. It points out that the application dose is usually 
determined on the basis of the nutrient content, but it is exactly the character of the substance to be delivered and its potential pollutant content that may affect it. Therefore, even when all the input materials and the full technology are well known, a comprehensive examination of the fermentation residue may be recommended to enable the expert to decide whether the substance is classified in accordance with points 2.7 or 2.8 of Annex 2 of this decree, or paragraph 3.1 of Annex 3, since this classification will be the basis for further examinations.

"2:11. Soil protection plan for the application of harmless wastes from non-agricultural sources to arable land. The application of harmless wastes from non-agricultural sources to arable land is allowed only if their application does not entail a negative change in soil quality (...) "

On-the-spot soil sampling, laboratory testing of soil samples and laboratory testing of the waste to be applied (a test report issued by an accredited laboratory for the harmless waste material from nonagricultural sources) shall be carried out before the plan is prepared.

"(...) The plan shall include the amount of material to be applied (ton/ha, $\mathrm{m}^{3} / \mathrm{ha}$ ), which shall be based on the nutritional requirements of the substance, the nutrient content of the soil, and, if necessary the water management properties of the soil and the crop grown or to be grown, as well as the technology of application."

If the fermentation residue does not contain heavy metals, hydrocarbons, human pathogenic agents, etc., while its other essential properties meet the criteria of 2.7, then the provisions of this clause apply to the soil protection plan (restrictions, clearance distances, sampling, test circle, content requirements). Obviously, the substance in question is not slurry but a material of similar characteristics.

\section{"2.7. Soil protection plan for the application of slurry to arable land}

Slurry is (...) a liquid by-product of animal husbandry consisting of animal feces, urine, excess drinking water, and technological water, and can only be hydraulically transported. (...) The ground sampling points to be used for the application of slurry to agricultural land should be selected so that they characterize the pedology of the area, while also revealing the vulnerable points in the soil, in particular deeper sites, which are close to settlements and risked by confluence. (...)

Laboratory tests:

(a) laboratory testing of soil samples

(aa) parameters to be tested for each layer sample in every 25 ha: $\mathrm{pH}\left(\mathrm{H}_{2} \mathrm{O}\right)$, plasticity index $\left(\mathrm{PI}_{\mathrm{A}}\right)$, humus content (\%), $\mathrm{NO}_{3}{ }^{-}+\mathrm{NO}_{2}{ }^{-}$nitrogen, total carbonate content $\left(\mathrm{CaCO}_{3} \%\right)$ or hydrolysis acidity (y1), \% of water-soluble salts.

ab) Parameters to be examined from characteristic sections: mechanical composition and bulk density test, salt composition from 1:5 aqueous ground extract ( $0.15 \%$ water soluble salt content), base exchange test

ac) tests to be carried out from the composite samples

- nutrient test from a 0-30 cm soil layer sample taken per 5 ha $\left(\mathrm{pH}\right.$, humus content, $\mathrm{Pl}_{\mathrm{A}}$, total water soluble salts, $\mathrm{CaCO}_{3}$ or hydrolytic acidity, $\mathrm{NO}_{3}{ }^{-}+\mathrm{NO}_{2}{ }^{-}$nitrogen, $\mathrm{K}_{2} \mathrm{O}, \mathrm{P}_{2} \mathrm{O}_{5}, \mathrm{Na}, \mathrm{Mg}, \mathrm{SO}_{4}{ }^{2-}, \mathrm{Cu}, \mathrm{Zn}, \mathrm{Mn}$ ),

ad) parameters to be evaluated in professionally justified cases: critical groundwater level determination, depth of salt maximum, salt flow calculations

ae) Calculated parameters: aggregate porosity, differentiated porosity, air capacity, relative air content, water-air ratio, $\mathrm{pF}$ line.

b) laboratory test of the slurry to be applied (from a representative composite sample): total nitrogen, nitrate, ammonium, $\mathrm{K}_{2} \mathrm{O}, \mathrm{P}_{2} \mathrm{O}_{5}$, salt content, dry matter, organic matter.

c) laboratory analysis of groundwater: general water chemistry test $(\mathrm{pH}$, total dissolved solids, conductivity $\mathrm{Cl}, \mathrm{CO}_{3}{ }^{2-}, \mathrm{HCO}_{3}{ }^{-}, \mathrm{SO}_{4}{ }^{2-}, \mathrm{NO}_{3}{ }^{-}, \mathrm{PO}_{4}{ }^{3-}, \mathrm{NH}_{4}{ }^{+}, \mathrm{K}, \mathrm{Ca}, \mathrm{Mg}, \mathrm{Na}, \mathrm{Na} \%, \mathrm{Mg} \%$, phenolphthalein alkalinity, soda equivalence)."

The provisions of paragraph 2.8 differ significantly from those set out in 2.7. The sampling method is different, the test circle is different, the content requirements are different, and it places special emphasis 
on taking into account the requirements set out in separate legislation and on applying them during the design process.

\section{"2.8. Soil protection plan for the agricultural application of waste water and sewage sludge}

The technical requirements for the application of waste water and sewage sludge to agricultural areas and the parameters that prohibit the application are defined by a separate regulation, the provisions of which must be entirely taken into account when making the soil protection plan. (...)

Soil sections should be explored for every soil patch, but at least for every 10 hectares. A sample of the genetic levels or layers of the soil section shall be taken. In case of soil patches with various physical and water management properties, an undisturbed soil sample must be collected from the so-called "typical soil section" (from a maximum of every 50 hectares, but at least from 1 section).

For nutrient testing, an average sampling from every 5 ha from $0-25 \mathrm{~cm}$ soil layers is required, also from $25-60 \mathrm{~cm}$ for injections. If groundwater is available within $5 \mathrm{~m}, 1$ water sample per 50 hectares, if it is available within 3-1.5 m, two water samples per 50 hectares are to be taken."

Note here that, under Government Decree No. 50/2001. (IV. 3.), the agricultural use of waste water and sewage sludge is a licensed activity, which should be approved by the soil protection authority. The prerequisite for this is the preparation of a soil protection plan for the agricultural application of waste water and sewage sludge [21].

The amount of waste water and liquid sewage sludge is determined primarily by the water management properties of the soil, its water balance, its nutrient content, the amount of toxic and harmful elements found in it, as well as by the water needs and nutrient (mainly nitrogen) requirements of the crop to be grown. The method and frequency of use, the amount of waste water to be used and the quantities of toxic elements and pollutants that can be discharged into the waste water shall be recorded in the soil protection plan on the basis of the calculation of the loads up to a maximum cultivation depth of $25 \mathrm{~cm}$. Knowing the properties of the material to be applied and the characteristics of the given agricultural area, a soil expert prepares a soil protection plan for the application (in possession of accredited laboratory protocols).

"The investigation of soil, waste water and sewage sludge is required by separate legislation (see Table 2 and Table 3). The plan must include the following:

- the determination of soil suitability for the agricultural use of waste water and sewage sludge,

- the analysis of the test parameters of waste water and sewage sludge,

- the determination of soil load (application technology),

- the amount of waste water and sewage sludge used,

- a proposal for supplemental nutrition,

- the determination of the conditions for the use of waste water and sewage sludge,

- $\quad$ anticipating the adverse events that may arise in the area, suggesting their prevention,

- $\quad$ suggestions for other interventions (deep loosening, crop range, etc.)

- a proposal to determine the time and frequency of control,

- where appropriate, the water balance sheet,

- the presentation of the underground water conditions of the site"

During composting some changes develop that are favorable for the impact of the starting materials on the soil. Due to the character of the fermentation residue, however, there may still be substances that may limit the application of the compost-like material. In this case, the provisions of paragraph 3.1 Annex 3 of FVM Decree No. 90/2008. (VII. 18.) shall apply, in the form of a simplified soil protection plan, but in any event having regard to the provisions laid down in separate legislation [20]. Note here that, pursuant to Government Decree No. 50/2001. (IV. 3.), the agricultural use of sewage sludge compost is a licensed activity authorized by the soil protection authority [21]. Its prerequisite is the preparation of a simplified soil protection plan for the agricultural use of sewage sludge compost. 
"3.1. A simplified soil protection plan for the agricultural use of sewage sludge compost

The technical requirements for the agricultural use of sewage sludge compost and the non-use parameters are determined by separate legislation.

A composite sample should be taken (...) from 20 subsamples collected from sample areas created in up to 5 hectares, from a depth depending on the type of crop.

The test parameters for soil and sewage sludge compost are contained in separate legislation.

In light of the above, the simplified soil protection plan should include the following:

- for the use of sewage sludge compost, the determination of soil suitability and other conditions

- the analysis of the test parameters of sewage sludge compost

- the determination of soil load, which must also consider the nutrition supply of soil and the nutritional requirements of plants,

- a load capacity chart for different crops,

- the indication of regional vulnerability according to the separate legislation,

- public health and environmental protection distances,

- the determination of waiting time under separate legislation,

- a proposal for other interventions,

- a proposal for the frequency of inspection."

Waste water, sewage sludge and sewage sludge composts are invariably subject to the provisions of Government Decree No. 50/2001. (IV. 3.) [21]. The testing and qualification of the fermentation residue determines the method of soil and water testing methods and the parameters to be tested, which are contained in the tables of the annexes of the regulation.

\section{CONTROLLING AND MONITORING}

The official revision and supervision of soil protection plans created for land applications are regulated according to the law. The control plans shall be created according to the provisions of points 2.7., 2.8. of Annex 2, 3.1. of Annex 3 of FVM Decree No. 90/2008. (VII. 18.) [20], and as prescribed by the licensing authority. The tests should cover all the previously investigated or prescribed parameters. Comparison with the previous data series has a monitoring purpose (among others).

In addition, it is a requirement for the land user to undertake soil-protecting farming activities adapted to the ecological conditions of the site, respecting the main management requirements set out in Act CXXIX of 2007 [10], in particular with regard to the conservation of organic matter in soil and to the activities pursuing an environmentally friendly nutrient management. Note also that in case of violation of these obligations, the soil protection authority is entitled to impose a soil protection fine.

The government operates a nationwide Soil Protection Information and Monitoring System for the continuous monitoring of the quality changes of the soils and their environmental conditions. Based on this system, excellent background databases were developed for practical use [22].

The monitoring of the pedological research of biogas production projects primarily involves the continuous examination of the fermentation residue and the soils affected by its land application. In addition to compulsory inspections FVM Decree No. 90/2008. (VII. 18.) 5.2.3. paragraph of Annex 5 On the monitoring of the application of harmless wastes from non-agricultural sources to agricultural areas) [20], the methodology of the Soil Information and Monitoring System can provide a good supplement and may offer new research opportunities. The baseline is recorded in the first year, according to the requirements of the soil protection plan, without which no authorization can be realized. Depending on the temporal variability of soil properties, the testing of monitored parameters should be repeated annually, or every 3 or 6 years (Tab. 2). 
Table 2. Soil characteristics to be defined by the Soil Protection Information and Monitoring System (according to the Soil Protection Information System methodology)

\begin{tabular}{|c|c|c|c|c|}
\hline Soil characteristic to be determined & Baseline & Annually & $\begin{array}{l}\text { Every } \\
3 \text { years }\end{array}$ & $\begin{array}{l}\text { Every } \\
6 \text { years }\end{array}$ \\
\hline Bulk density & $*$ & & & \\
\hline Mechanical composition & $*$ & & & \\
\hline Plasticity index according to Arany $\left(\mathrm{PI}_{\mathrm{A}}\right)$ & $*$ & & & \\
\hline Hygroscopicity (hy2) & $*$ & & & \\
\hline Total water capacity (pF0) & $*$ & & & \\
\hline Outdoor water capacity ( $\mathrm{pF} 2.5$ ) & $*$ & & & \\
\hline Unavailable hygroscopic water content ( $\mathrm{pF} 4.2)$ & $*$ & & & \\
\hline Amount of available water $(\mathrm{pF} 2.5-\mathrm{pF} 4.2)$ & $*$ & & & \\
\hline $\begin{array}{r}\mathrm{CaCO}_{3} \text {-content if }>5 \% \\
\text { if } 1-5 \% \\
\text { if }<1 \% \\
\end{array}$ & $\begin{array}{l}* \\
* \\
*\end{array}$ & $*$ & $*$ & $*$ \\
\hline $\begin{aligned} & \mathrm{pH} \text { in distilled water if } \mathrm{CaCO}_{3} \text { content }>1 \% \\
&< 1 \% \\
&\end{aligned}$ & * & $*$ & $*$ & \\
\hline $\begin{aligned} & \mathrm{pH} \text { in } \mathrm{nKCl} \text { if } \mathrm{CaCO}_{3} \text { content }>1 \% \\
&<1 \% \\
&\end{aligned}$ & $*$ & $*$ & $*$ & \\
\hline Hydrolysis acidity, if soil is not carbonated & $*$ & $*$ & & \\
\hline Exchange acidity, if soil is not carbonated & $*$ & $*$ & & \\
\hline Total water soluble salts & $*$ & & & $*$ \\
\hline Total salts, saline soils or those prone to salinisation & $*$ & $*$ & & \\
\hline $\begin{array}{l}\text { Analysis of aqueous extract in the proportion of } 5: 1 \\
\left(\mathrm{CO}_{3}^{2-}, \mathrm{HCO}_{3}^{-}, \mathrm{Cl}^{-}, \mathrm{SO}_{4}{ }^{2-}, \mathrm{Ca}^{2+}, \mathrm{Mg}^{2+}, \mathrm{Na}^{+}, \mathrm{K}^{+}\right) / \text {soils } \\
\text { with higher salinity/ }\end{array}$ & $*$ & & & $*$ \\
\hline Soda alkaline (saline soils) & $*$ & & $*$ & \\
\hline Organic matter content & $*$ & & $*$ & \\
\hline Adsorption capacity & $*$ & & & $*$ \\
\hline Exchangeable cations $\left(\mathrm{Ca}^{2+}, \mathrm{Mg}^{2+}, \mathrm{Na}^{+}, \mathrm{K}^{+}\right)$ & $*$ & & & $*$ \\
\hline Total $\mathrm{N}$ content & $*$ & & $*$ & \\
\hline Nitrate-nitrite content & $*$ & $*$ & & \\
\hline $\begin{array}{l}\text { Amount of "available" plant nutrients }(\mathrm{P}, \mathrm{K}, \mathrm{Ca}, \mathrm{Mg}, \mathrm{Cu} \text {, } \\
\mathrm{Zn}, \mathrm{Mn}, \mathrm{Na}, \mathrm{Fe}, \mathrm{B}, \mathrm{Mo})\end{array}$ & $*$ & & $*$ & \\
\hline $\begin{array}{l}\text { Amount of "toxic" elements (or elements which may } \\
\text { become toxic) (Al, As, B, Cd, Co, Cr, Cu, Hg, Mn, Mo, } \\
\mathrm{Ni}, \mathrm{Pb}, \mathrm{Zn} \text { ) }\end{array}$ & $*$ & & $*$ & \\
\hline $\begin{array}{l}\text { Cellulose test for the biological activity, } \\
\text { dehydrogenase activity, } \\
\text { to characterize } \mathrm{CO}_{2} \text { production of the soil }\end{array}$ & $\begin{array}{l}* \\
* \\
*\end{array}$ & & $\begin{array}{l}* \\
* \\
*\end{array}$ & \\
\hline Natural radioactivity & $*$ & & $*$ & \\
\hline $\begin{array}{l}\text { Chemical composition of groundwater } \\
\left(\mathrm{pH}, \mathrm{EC}, \mathrm{CO}_{3}^{2-}, \mathrm{HCO}_{3}^{-}, \mathrm{Cl}^{-}, \mathrm{SO}_{4}{ }^{2-}, \mathrm{Ca}^{2+}, \mathrm{Mg}^{2+}, \mathrm{Na}^{+}, \mathrm{K}^{+},\right. \\
\left.\mathrm{NO}_{3}^{--}, \mathrm{NO}_{2}^{-}, \mathrm{PO}_{4}{ }^{3-}\right)\end{array}$ & $*$ & $*$ & & \\
\hline
\end{tabular}

In order to maintain an environment that ensures a good quality of life, we need adaptability, constructive co-operation and responsible thinking, which is partly based on farming tailored to local conditions, circumstances and needs [23]. If we make these concerns our principles, fermentation residues from biogas 
plants can be applied to agricultural land. However, the varying character of the material requires that the main emphasis is placed - besides on nutrition management - on the protection of arable land during application. All this requires responsible and law-abiding behaviour, as well as co-operation as mentioned above from the plant that wishes to dispose of the fermentation residue, the soil expert, the pedologic designer of the application plan, the laboratory accredited to carry out tests and the licensing authorities alike.

\section{REFERENCES}

[1] Gy. Várallyay, Soil Data-Base for Long-term Field Experiments and Sustainable Land Use, Agrokémia és Talajtan, 43 (1994), pp. 269-290

[2] P. Stefanovits, E. Micheli (ed), A talajok jelentősége a 21. században, MTA Társadalomkutató Központ, Budapest 2005

[3] T. Harrach, Bodebewertung für die Landwirtshaft und den Naturschutz, Kulturtechnik und Flurbereinigung 28, Werlag Paul Parey, Berlin und Hamburg 1987, pp. 184-190

[4] S. Evangelisti, P. Lettieri, D. Borello, R. Clift, Life cycle assessment of energy from waste via anaerobic digestion: A UK case study, Waste Management 34 (2014) pp. 226-237

[5] Ch. Freeman, L. Pyle, Methane generation by anaerobic fermentation, I.T. Publications Ltd., London 1977

[6] E. Q. Kissné, A biogáz, Mezőgazdasági Könyvkiadó, Budapest 1983

[7] M. M. Kononova, Soil organic matter (book reviews), Soil Science, 95 (1) (1963), p 90

[8] M. Schnitzer, S. U. Khan, Soil organic matter, E-book, Elsevier Science 1978, 318 p

[9] FAO Soils Bulletin 80 - The importance of soil organic matter; Food and Agriculture Organization of the United Nations, Rome 2005, 94 p

[10] Act CXXIX of 2007 on the Protection of Arable Land (including Act No. XLV of 2015 amending this Act)

[11]P. Stefanovits, Talajtan. Mezőgazdasági Kiadó, Budapest 1975.

[12] Gy. Várallyay, Talaj az agro-ökoszisztémák alap-eleme, „AGRO-21” Füzetek (37) (2004), pp. 33-49

[13]T. Harrach, Funktionen und Schutzbedingungen von Böden, Böden in Hessen - Ökologie-Forum, Studio Zerzawy, Burg Hohenstein 1992, pp. 9-11

[14]J. Ángyán, Z. Menyhért (eds), Alkalmazkodó növénytermesztés, környezet- és tájgazdálkodás, Szaktudás Kiadó Ház, Budapest 2004

[15]COM(2006)231: Thematic Strategy for Soil Protection

[16]COM(2006)232: Framework for the Protection of Soil

[17]Regulation (EU) No 1306/2013 on the financing, management and monitoring of the common agricultural policy

[18] Act LIII of 1995 on the General Rules of Environmental Protection

[19] Act LIII of 1996 on the General Rules of Nature Protection

[20]FVM (Ministry for Agriculture and Rural Development in Hungary) Decree No. 90/2008. (VII. 18.) on the detailed rules of preparing soil protection plans

[21] Government Decree No. 50/2001. (IV.3.) On the application and treatment of waste water and sludge in agricultural activities

[22]I. Juhász (ed): Magyarország talajainak állapota a Talajvédelmi Információs és Monitoring Rendszer (TIM) adatai alapján, Földmüvelésügyi és Vidékfejlesztési Minisztérium, Budapest 2007

[23] V. Nagy, Agri-environmental actions for the protection of soil, University of Szeged, Szeged 2015 